Mohammad Ali Semsarzadeh and Alireza Aghili

\title{
ETHYLENE EXTRUSION POLYMERIZATION BY HETEROGENEOUS BI-SUPPORTED ZIEGLER-NATTA CATALYSTS
}

\author{
Polymer Engineering Group, Tarbiat M odares University, Jalal Al-e-Ahmad Highway, \\ Tehran, PO. Box: 14115-111, Iran \\ semsarzadeh@modares.ac.ir
}

Received: J uly 28, 2008

(C) Semsarzadeh M., Aghili A., 2009

\begin{abstract}
The MCM-41 (Mobil Composition of Matter) and SBA-16 (Santa Barbara Amorphous) supported $\mathrm{TiCl}_{4}$ and $\mathrm{TiCl}_{4} / \mathrm{MgCl}_{2}$ catalysts with different molar ratios of $\mathrm{Mg} / \mathrm{Ti}$ were synthesized and used for ethylene polymerization under atmospheric pressure. The nanochannels of these supports serve as a nanoscale polymerization reactor and the polyethylene nanofibers were extruded during the reaction. The effect of $\mathrm{MgCl}_{2}$ on catalytic activity and morphology of resulting polyethylene has been investigated too. $\mathrm{MgCl}_{2}$ has enhanced the catalytic activities and made the SBA- $16 / \mathrm{MgCl}_{2} / \mathrm{TiCl}_{4}$ catalytic system has fibrous morphology.
\end{abstract}

Keywords: Ziegler-Natta polymerization, polyethylene, extrusion polymerization, nanofiber.

\section{Introduction}

In recent years the production of polyolefins is continuously growing and predicted to rise at a high rate. Intense research has been carried out on olefin polymerization catalysis, in order to develop new catalytic systems capable of producing new materials, as well as developing more economic and versatile processes.

Different kinds of metal halides or oxides have been used as a support of the catalyst for olefin polymerization. $\mathrm{MgCl}_{2}$ has been reported as a good support for preparation of highly active Ziegler-Natta catalysts. Inorganic compounds such as silica and alumina, when used as a support of polymerization catalysis, play an important role in controlling the morphology of growing polymer particles, due to a large surface area and wide range of pores size distribution. It is possible to control the catalytic activity as well as morphology of growing particles by using bisupported Ziegler-Natta catalysts [1-3].

To control the morphology of resulting polymer, mesoporous materials with constrained geometries can be expected to be suitable supports for catalyst preparation. That is why many attempts have been made to prepare the $\mathrm{Si}$ and/or $\mathrm{Al}$ based mesoporous structures with a larger surface area and more uniform pore size distribution than conventional silica and/or alumina. Mesoporous Silica Fiber (MSF), Mobil Composition of Matter (MCM-41), Santa Barbara Amorphous (SBA-15), Anodized Aluminum Oxide (AAO) and alumino-silicate (Al-MCM-41, Al-SBA-15) structures with regular, ordered hexagonal pores and narrow pore size distribution are the examples which have been used as a support for preparing heterogeneous catalysts. The geometrical shape of the nanochannels can serve as nanoscale polymerization reactors [4-5] to affect the pattern of a monomer insertion and to control polymer chain structure and morphology. Polyethylene nanofibers, a new morphology of synthesized polymers were prepared for the first time by Aida et al. [6] with MSF supported titanocene catalyst via a polymerization process termed as extrusion polymerization. MCM-41, SBA-15, AAO and alumino-silicate structures have been used as support of metallocene and Ziegler-Natta catalysts for polymerization of ethylene or propylene [5, 7-23]. The major morphology of polymers prepared by these catalytic systems is polyethylene nanofibers or confined PE and PP.

In this study MCM-41 and SBA-16 supported $\mathrm{TiCl}_{4} /$ $\mathrm{MgCl}_{2}$ catalysts were synthesized and used for ethylene polymerization under atmospheric pressure. The effect of $\mathrm{MgCl}_{2}$, as the second support, on the morphology of resulting polyethylene was investigated.

\section{Experimental}

\subsection{M aterials}

All manipulations involving air and/or water sensitive compounds were performed under nitrogen atmosphere. $n$-Hexadecyltrimethylammonium bromide, aqueous ammonia (reagent grade $25 \mathrm{wt} \%$ ), titanium tetrachloride, anhydrous magnesium chloride and tetrahydrofuran were purchased from Merck. Tetraethoxysilane (TEOS) was purchased from Acros. Triethylaluminium ( $\mathrm{AlEt}_{3}$ ) was 
purchased from Aldrich. Pluronic F127 was purchased from Sigma. Polymerization-grade ethylene and nitrogen, both with purity of $99.999 \%$ were passed through the columns of silica gel with 3 and $4 \AA$ molecular sieves. Hexane was distilled and refluxed over sodium wire with benzophenone as an indicator then distilled again before use.

\subsection{Preparation of Catalyst Systems and Ethylene Polymerization}

MCM-41 and SBA-16 powders were prepared according to the literature [24-25] and were treated in flowing ultrahigh-purity nitrogen at $673 \mathrm{~K}$ for $9 \mathrm{~h}$ before use in catalyst preparation.

The MCM-41 and SBA-16 supported $\mathrm{TiCl}_{4}$ and $\mathrm{TiCl}_{4} / \mathrm{MgCl}_{2}$ catalysts were synthesized by anchoring $\mathrm{Ti} / \mathrm{Mg}$ bimetallic complex into the nanochannels of the supports, in the same way discussed in our previous work [23].

The ethylene polymerization was carried out in a $250 \mathrm{ml}$ round bottom flask with a Teflon stirrer under atmospheric pressure. Hexane and catalyst were added into the flask. The mixture was saturated with ethylene and stirred for several minutes. At the temperature of $323 \mathrm{~K}$ polymerization was initiated by adding an appropriate amount of $\mathrm{AlEt}_{3}$ to the reactor. The reaction was terminated at fixed time by adding of dilute hydrochloric acid solution in methanol. The polymer was filtered and then dried at $333 \mathrm{~K}$ overnight.

\subsection{Characterization of Supports and Polymers}

The X-ray powder diffraction (XRD) spectra were recorded on a Philips X'pert diffractometer. The nitrogen adsorption-desorption isotherms were measured at BELSORP-mini adsorption apparatus. The specific surface area of supports was obtained based on the BET (Brunauer, Emmett, and Teller) method. The mean pore diameter was calculated using BJH (Barrett-Joyner-Halenda) method. A scanning electron microscopy (Philips XL30) was used for investigating the morphology of supports and polymers. The samples were deposited on a sample holder and sputtered with gold.

\section{Results and Discussion}

\subsection{Characterization of Supports}

Fig. 1 shows the XRD spectra of MCM-41 and SBA-16. These spectra can be indexed on 2D hexagonal and the cubic Im $3 m$ structures for MCM-41 [24] and SBA16 [25-26] respectively.

Fig. 2 shows the nitrogen adsorption-desorption isotherm of the MCM-41 and SBA-16. The adsorption and desorption isotherms of nitrogen on the samples show the typical type IV isotherm according to the IUPAC nomenclature for MCM-41 [24] and SBA-16 [25-26], respectively. Table 1 summarizes the structure parameters of MCM-41 and SBA-16, including specific surface area, mean pore diameter and pore volume from the nitrogen adsorption- desorption analysis.

Figs. 3 and 4 show the SEM micrograph of MCM41 and SBA-16, respectively. The MCM-41 has rod-like structure of about $1-3 \mu \mathrm{m}$ in length and about $0.5 \mu \mathrm{m}$ in diameter. The SBA-16 particles with the size around 5 $\mu \mathrm{m}$ are made of the aggregation of particles with a submicrometric size.

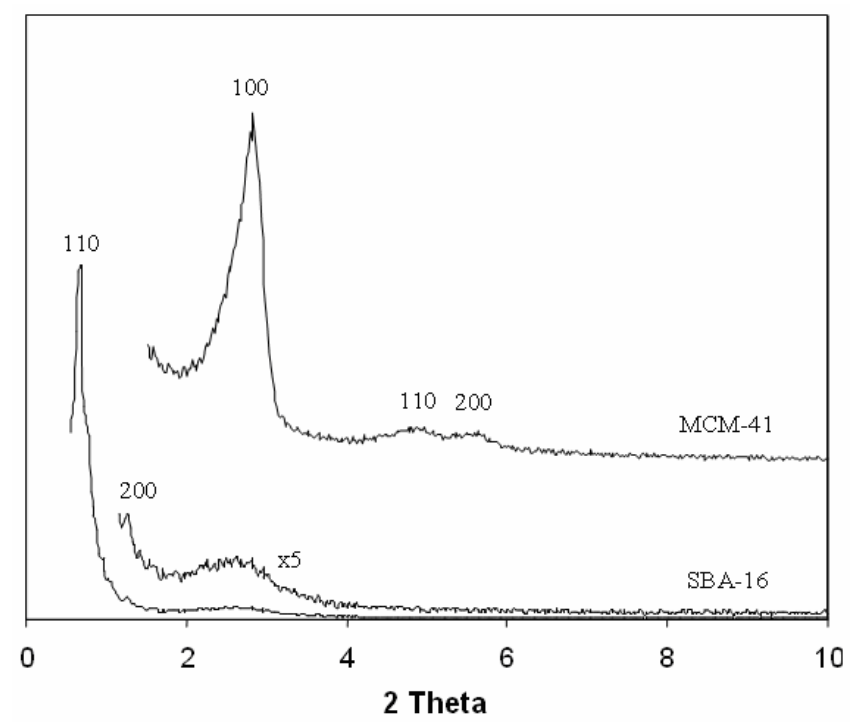

Fig. 1. X-ray diffraction patterns of MCM-41 and SBA-16

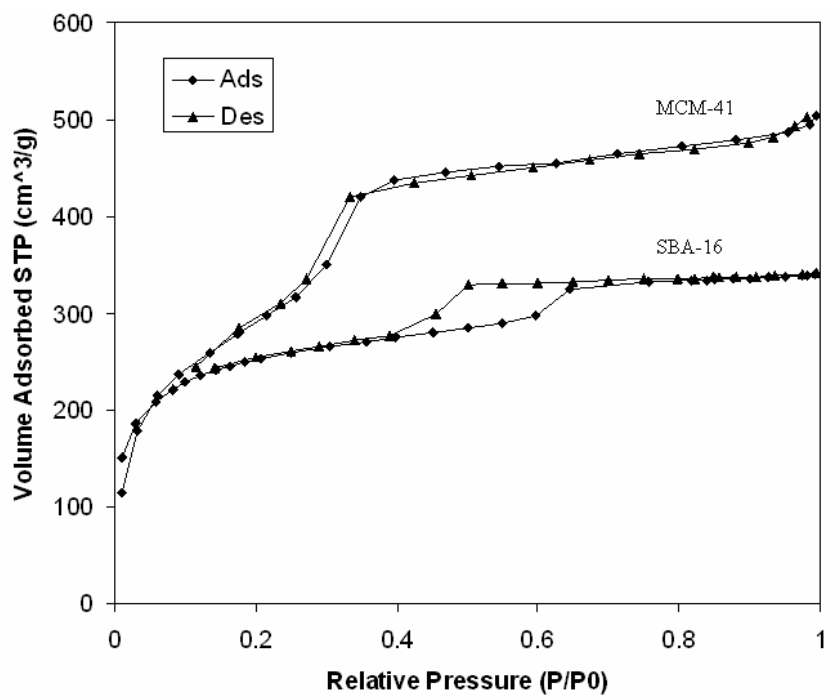

Fig. 2. Nitrogen adsorption-desorption isotherm of MCM-41 and SBA-16 
Structure parameters for the supports ${ }^{\mathrm{a}}$

\begin{tabular}{|l|c|c|c|}
\hline Support & $S_{B E T}{ }^{\mathrm{b}}, \mathrm{m}^{2} / \mathrm{g}$ & $V_{p}{ }^{\mathrm{c}}, \mathrm{ml} / \mathrm{g}$ & $d_{p}{ }^{\mathrm{d}}, \AA$ \\
\hline MCM-41 & 1070 & 0.78 & 26.8 \\
\hline SBA-16 & 809 & 0.52 & 53.4 \\
\hline
\end{tabular}

${ }^{a} S_{B E T}$ is BET specific surface area; $V_{p}$ is specific pore volume; $d_{p}$, is pore diameter; ${ }^{\mathrm{b}}$ data from BET equation; ${ }^{\mathrm{c}}$ data from adsorption; d data from $\mathrm{BJH}$ calculation

\subsection{Characterization of Catalysts}

Titanium and magnesium loadings on the supports were determined by Inductively Coupled Plasma-Mass Spectroscopy (ICP-MS). The results are shown in Table 2. MCM-41 has a larger surface area than SBA-16 and more $-\mathrm{OH}$ groups per mass unit of supports are present on the surface for the reaction with $\mathrm{TiCl}_{4}$ or $\mathrm{TiCl}_{4} / \mathrm{MgCl}_{2}$ bimetallic complexes. So it is of evidence that more $\mathrm{Ti}$ and $\mathrm{Mg}$ are chemisorbed on the surface of MCM-41.

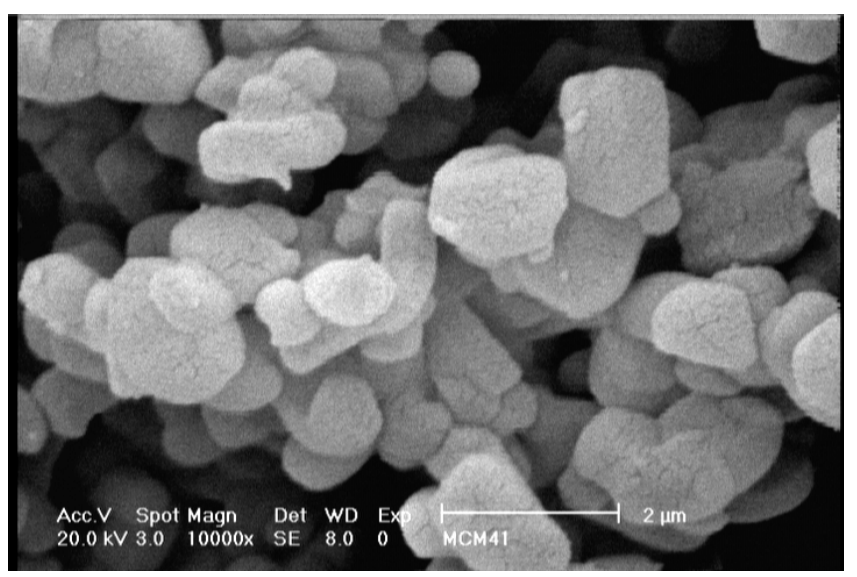

Fig. 3. SEM micrograph of the MCM-41

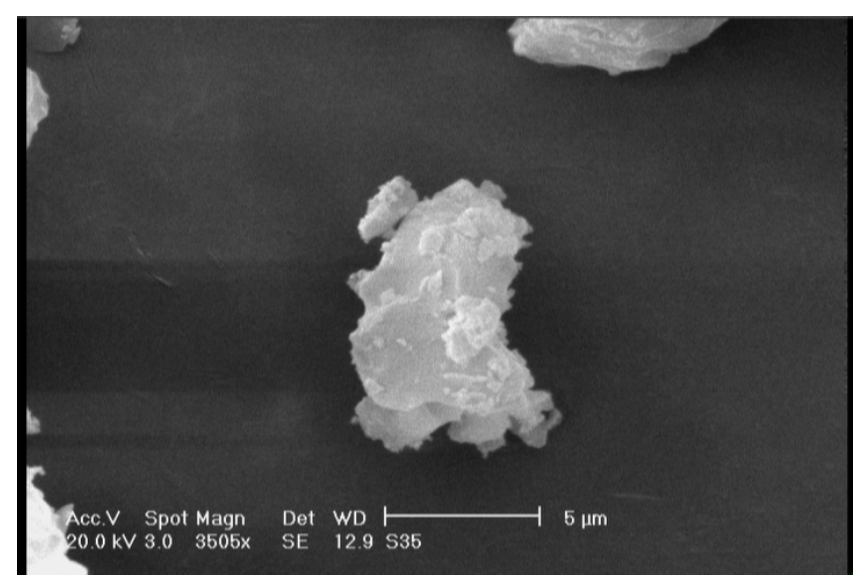

Fig. 4. SEM micrograph of the SBA-16
Chemisorbed elements on the catalysts

\begin{tabular}{|c|c|c|c|c|}
\hline Run & Catalyst & $\begin{array}{l}\text { Mole } \\
\text { ratio }^{\mathrm{a}} \\
\mathrm{Mg} / \mathrm{Ti}\end{array}$ & $\begin{array}{l}\text { Ti content, } \\
\mathrm{mmol} / \mathrm{g}-\mathrm{cat}\end{array}$ & $\begin{array}{l}\text { Mg content, } \\
\text { mmol/g-cat }\end{array}$ \\
\hline 1 & SBA-16/TiCl 4 & 0 & 0.142 & - \\
\hline 2 & SBA-16/MgCl $2 / \mathrm{TiCl}_{4}$ & 1 & 0.138 & 0.127 \\
\hline 3 & SBA-16/MgCl $2 / \mathrm{TiCl}_{4}$ & 2 & 0.144 & 0.214 \\
\hline 4 & MCM-41/ $\mathrm{TiCl}_{4}$ & 0 & 0.151 & - \\
\hline 5 & MCM-41/ $\mathrm{MgCl}_{2} / \mathrm{TiCl}_{4}$ & 1 & 0.154 & 0.123 \\
\hline 6 & MCM- $41 / \mathrm{MgCl}_{2} / \mathrm{TiCl}_{4}$ & 2 & 0.163 & 0.232 \\
\hline
\end{tabular}

${ }^{a}$ used in catalysts preparation

\subsection{Ethylene Polymerization}

The MCM-41 and SBA-16 supported $\mathrm{TiCl}_{4}$ and $\mathrm{TiCl}_{4} / \mathrm{MgCl}_{2}$ catalysts were used for ethylene polymerization. Fig. 5 shows the effect of $\mathrm{MgCl}_{2}$ on the catalytic activities. $\mathrm{MgCl}_{2}$ has enhanced the activities of both supported catalysts. The rate enhancement effect of $\mathrm{MgCl}_{2}$ in silica supported catalysts has been well discussed in the literature [1-3, 27-28]. $\mathrm{TiCl}_{4}$ in the presence of $\mathrm{MgCl}_{2}$ forms bimetallic complexes which are chemisorbed on the surface of the support and have higher activities than in the case when $\mathrm{TiCl}_{4}$ is used alone. Due to higher surface area, MCM-41 supported catalysts have shown a higher activity than SBA-16 supported catalysts.

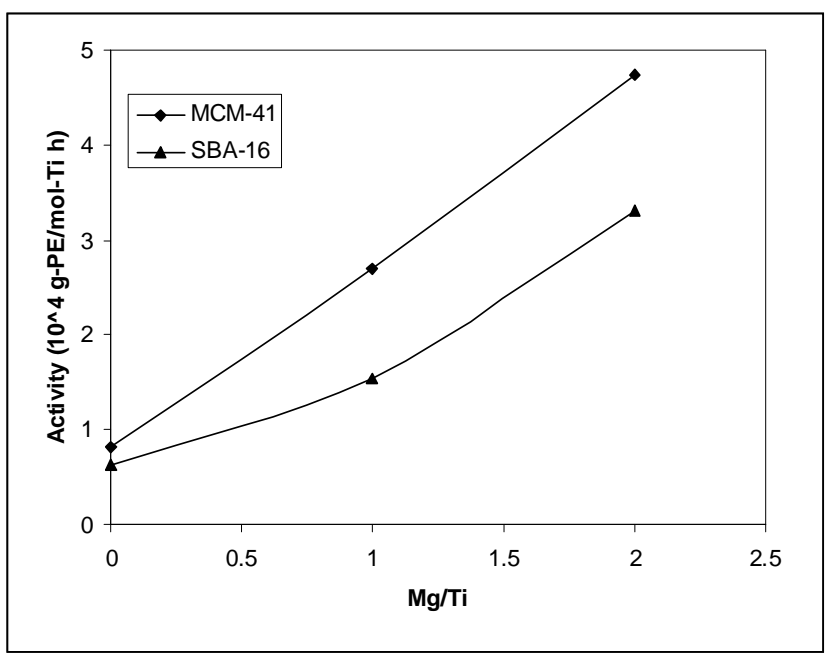

Fig. 5. Effect of $\mathrm{MgCl}_{2}$ on catalytic activities. (Solvent is hexane, $\mathrm{Al} / \mathrm{Ti}$ molar ratio is 30 , polymerization pressure is $101 \mathrm{kPa}$, temperature is $323 \mathrm{~K}$ and time is $30 \mathrm{~min}$.)

\subsection{The Morphology of the Resulting PE}

Morphological investigation of the resulting PE was conducted with SEM. Figs. 6, 7 and 8 show the SEM micrographs of the resulting PE prepared by MCM-41/ $\mathrm{MgCl}_{2} / \mathrm{TiCl}_{4}$ catalyst with $\mathrm{Mg} / \mathrm{Ti}$ molar ratios of 0,1 and 2 , respectively. These figures show that the $\mathrm{PE}$ has a fibrous morphology. 


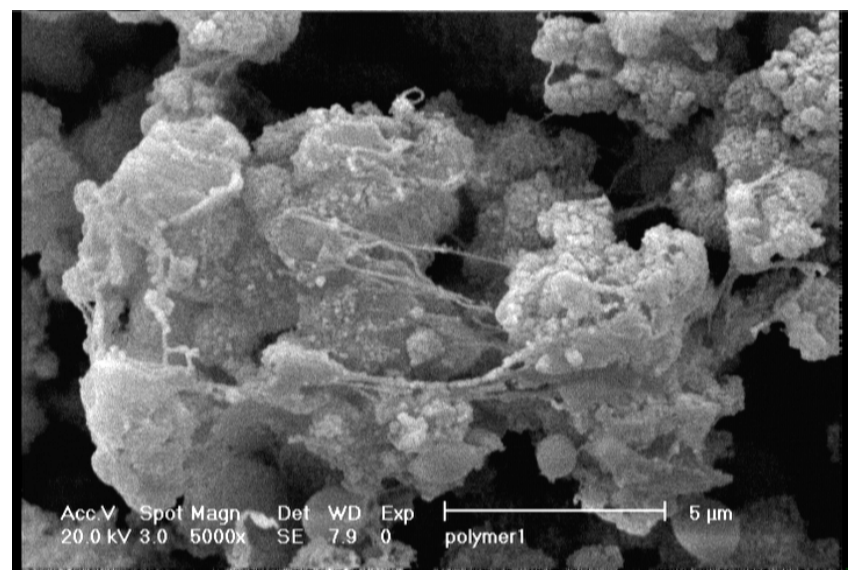

Fig. 6. SEM micrograph of the polyethylene prepared by MCM-41/ $\mathrm{TiCl}_{4}$ catalyst

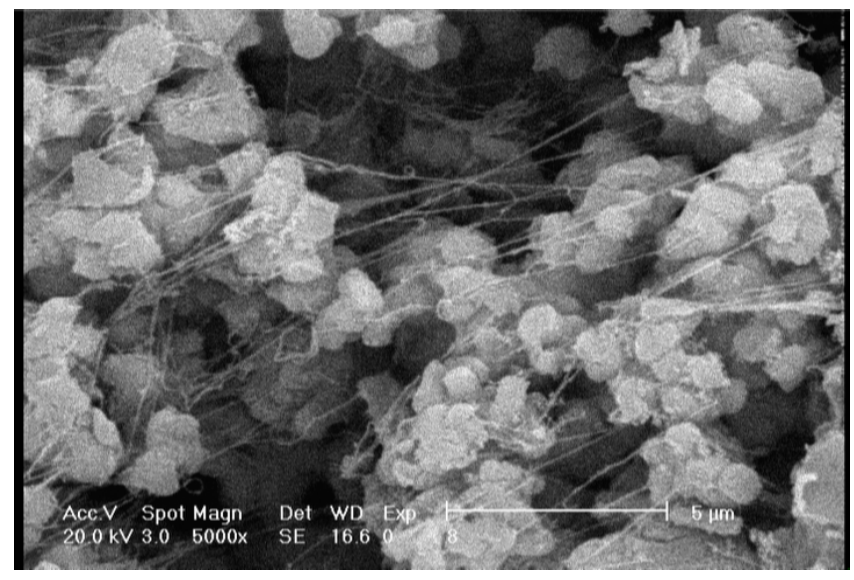

Fig. 7. SEM micrograph of the polyethylene prepared by $\mathrm{MCM}-41 / \mathrm{MgCl}_{2} / \mathrm{TiCl}_{4}$ catalyst $(\mathrm{Mg} / \mathrm{Ti}=1)$

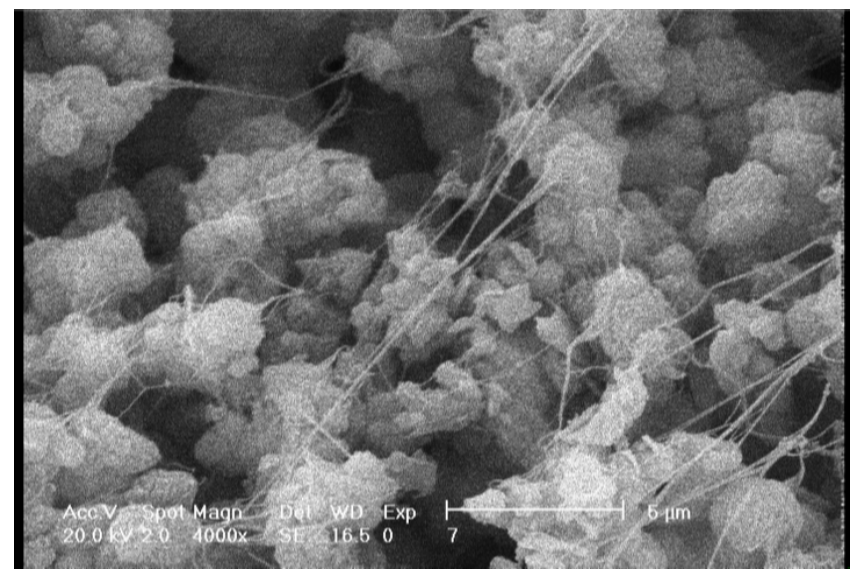

Fig. 8. SEM micrograph of the polyethylene prepared by $\mathrm{MCM}-41 / \mathrm{MgCl}_{2} / \mathrm{TiCl}_{4}$ catalyst $(\mathrm{Mg} / \mathrm{Ti}=2)$

The PE nanofibers result from the control of MCM-41 nanochannels to the direction and dimension of PE chains propagation [20]. MCM-41 consists of honeycomb shaped array of unidimensional, hexagonal
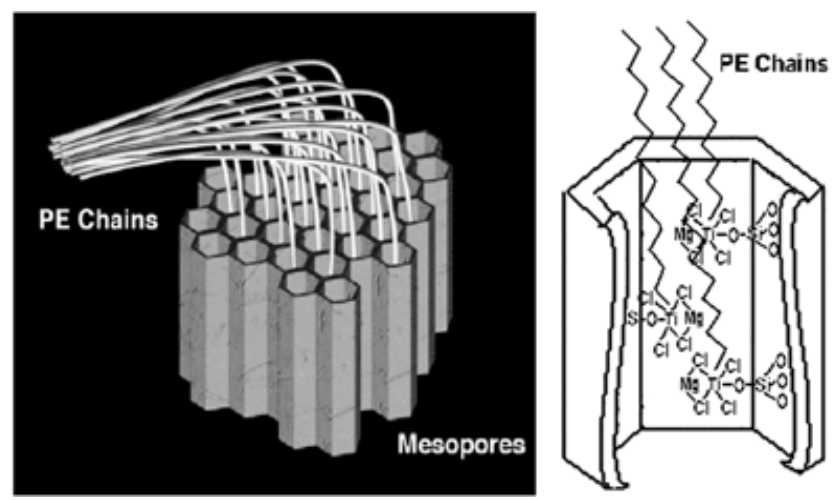

Fig. 9. Conceptual scheme for the growth of crystalline fibers of polyethylene

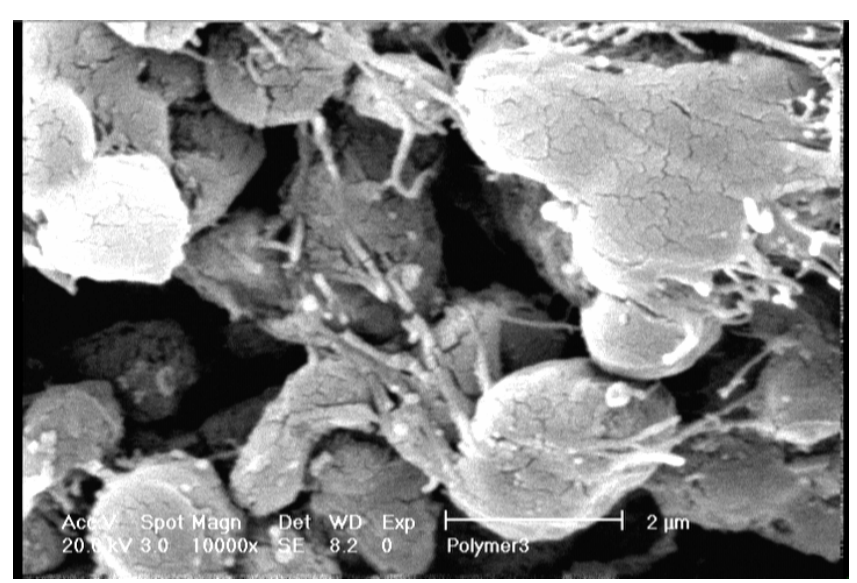

Fig. 10. SEM micrograph of the polyethylene prepared by SBA-16/ $\mathrm{TiCl}_{4}$ catalyst

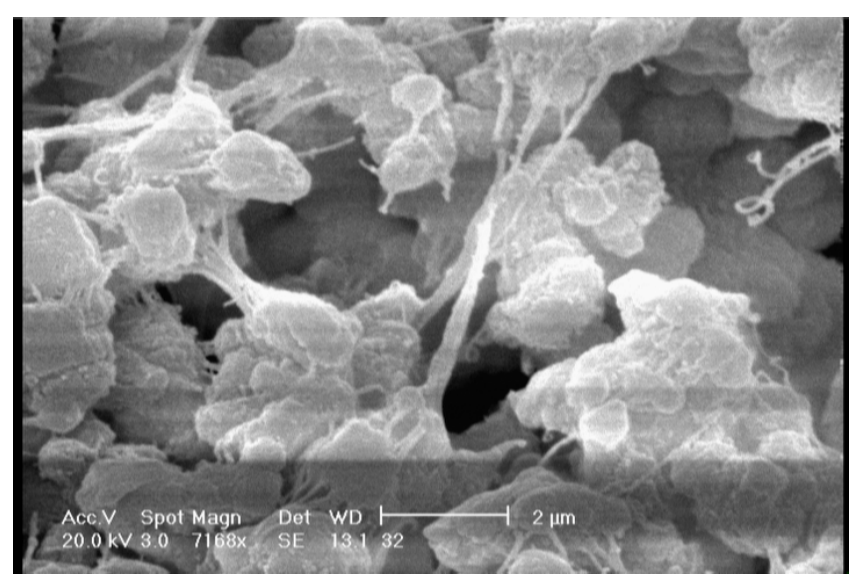

Fig. 11. SEM micrograph of the polyethylene prepared by SBA-16/ $\mathrm{MgCl}_{2} / \mathrm{TiCl}_{4}$ catalyst $(\mathrm{Mg} / \mathrm{Ti}=1)$

pores and the pore diameter $(29 \AA)$ is much smaller than the lamellar thickness $(270 \AA)$ of the folded-chain crystals of an ordinary polyethylene [29]. When the ethylene monomers pass into the channel, the wall of the channel 
can control the direction of ethylene propagation and the PE extended-chains are formed. Then these extendedchains grow out of MCM-41 nanochannels and assemble to form nanofibers (Fig. 9) [6].

Fig. 10 shows the SEM micrographs of the resulting PE prepared by SBA-16/ $\mathrm{TiCl}_{4}$ catalyst. This figure shows that the PE mainly has an amorphous morphology and a few nanofibers appeared on the surface of polymer particles. Figs. 11 and 12 show the SEM micrograph of PE prepared by $\mathrm{SBA}-16 / \mathrm{MgCl}_{2} / \mathrm{TiCl}_{4}$ catalysts with $\mathrm{Mg} / \mathrm{Ti}$ molar ratios of 1 and 2, respectively. When $\mathrm{MgCl}_{2}$ was used in SBA-16 supported catalysts, the resulting PE had a fibrous morphology.

The presence of $\mathrm{MgCl}_{2}$ in the preparation of SBA-16 supported catalyst made the resulting PE have more nanofibers. One possible reason may be the influence of polymerization rate on the formation of nanofibers growing out of nanochannels. SBA-16 has an Im3m cubic structure with cylindrical nanochannels. At lower polymerization rates, the chains growing out of nanochannels have longer time for relaxing and forming the floccules or folded chain crystals [20]. While at higher polymerization rates, they do not have enough time to relax and tend to be located in the extended chain crystals. In our results, when $\mathrm{MgCl}_{2}$ was used, the polymerization rate increased and evidently more nanofibers were formed.

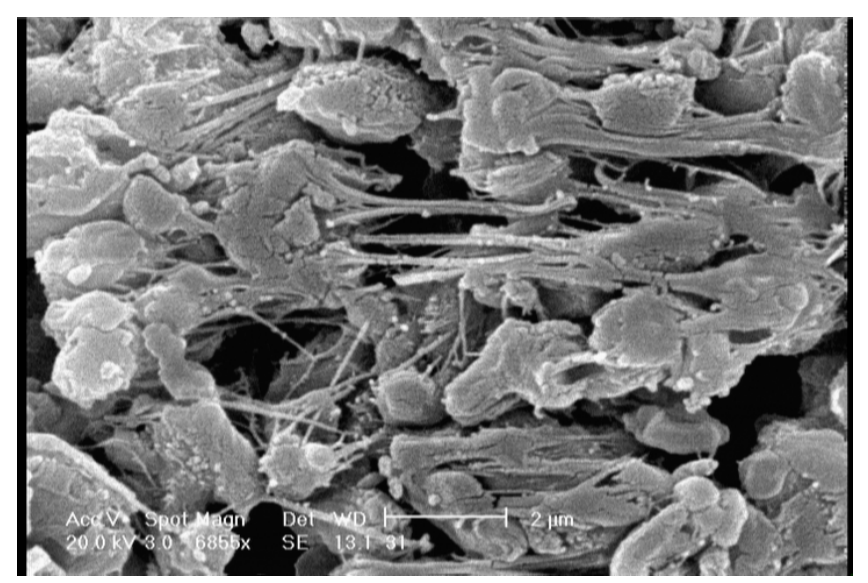

Fig. 12. SEM micrograph of the polyethylene prepared by SBA-16/ $\mathrm{MgCl}_{2} / \mathrm{TiCl}_{4}$ catalyst $(\mathrm{Mg} / \mathrm{Ti}=2)$

A comparison between the nanofibers prepared from MCM-41 and SBA-16 supported catalysts shows that MCM-41 leads to longer and thinner nanofibers. This may be related to the size of nanochannels diameter and to the catalytic activity as well. SBA-16 has a larger pore size which may contain more growing polymer chains. Also, due to lower activity, these extruded chains have more time to relax and have fewer tendencies to form longer fibers. Therefore, the PE prepared from SBA-16 supported catalysts has thicker and shorter nanofibers.

\section{Conclusions}

MCM-41 (Mobil Composition of Matter) and SBA16 (Santa Barbara Amorphous) supported $\mathrm{TiCl}_{4}$ and $\mathrm{TiCl}_{4} / \mathrm{MgCl}_{2}$ catalysts were synthesized for ethylene polymerization under atmospheric pressure. The active sites were formed inside the nanochannels of the supports. The ethylene monomer diffused into the channels and growing polyethylene chains were extruded to form nanofibers. PE nanofibers were prepared from MCM-41 supported catalysts. MCM-41 showed higher activity than SBA-16 supported catalysts. $\mathrm{MgCl}_{2}$ has enhanced the catalytic activities of both supports and made the SBA-16 supported catalysts have fibrous morphology in the resulting polyethylene.

\section{References}

[1] Lu H. and Xiao S.: Macromol. Chem., 1993, 194, 421.

[2] de Santa Maria L., Soga K. and Shiono T.: Macromol. Chem. Phys., 1994, 195, 2591.

[3] Kim I., Kim J. and Woo S.: J. Appl. Polym. Sci., 1990, 39, 837.

[4] Lehmus P. and Rieger B.: Science, 1991, 285, 2081.

[5] Sano T. and Yasunori O.: Catal. Surv. Asia, 2004, 8, 295.

[6] Kageyama K., Tamazawa J. and Aida T.: Science, 1999, 285, 2113.

[7] Ye Z., Zhu S., Wang W. et al.: J. Polym. Sci. B, 2003, 41, 2433.

[8] Turunen J. and Pakkanen T.: J. Molecul. Catalys. A, 2007, 263, 1.

[9] Dong X., Wang L., Wang J. et al.: J. Phys. Chem. B, 2006, $110,9100$.

[10] Nair S., Naredi P. and Kim S.: J. Phys. Chem. B, 2005, 109, 12491 .

[11] Chen S., Guo C., Liuc L. et al.: Polymer, 2005, 46, 11093.

[12] Kageyama K., Ng S., Ichikawa H. and Aida T.: Macromol. Symp., 2000, 157, 137.

[13] Guo C., Zhang D., Wang F. and Jin G.: J. Catal., 2005, 234, 356.

[14] Turunen J., Venalainen T., Suvanto S. and Pakkanen T.: J. Polym. Sci. A, 2007, 45, 4002.

[15] Guo C., Jin G. and Wang F.: J. Polym. Sci. A., 2004, 42, 4830.

[16] Dong X., Wang L., Wang W. et al.: Macromol. Mater. Eng., 2005, 290, 31.

[17] Nakajima H., Yamada K., Iseki Y. et al.: J. Polym. Sci. B, 2003, 40, 3324.

[18] Silveira F., Petry C., Pozebon D. et al.: Appl. Catal. A, 2007, 333, 96.

[19] Dong X., Wang L., Jiang G. et al.: J. Molecul. Catalys. A, 2005, 240, 239.

[20] Dong X., Wang L., Wang W. et al.: Eur. Polym. J., 2005, 41, 797. 
[21] Dong X., Wang L., Zhou J. et al.: Catalys. Commun., 2006, 7, 1 .

[22] Zhang W., Zhou S. and Zhang R.: Des. Monom. Polym., 2007, 10, 469.

[23] Semsarzadeh M. and Aghili A.: J. Macromol. Sci. A., accepted in Jan. 2008.

[24] Grun M., Unger K., Matsumoto A. and Tsutsumi K.: Micropor. Mesopor. Mater., 1999, 27, 207.

[25] Zhao D., Huo Q., Feng J. et al.: J. Am. Chem. Soc., 1998, 120, 6024.

[26] Kim T., Ryoo R., Kruk M. et al.: J. Phys. Chem. B, 2004, 108, 11480.

[27] Soga K., Ohnishi R. and Doi Y.: Polym. Bull., 1983, 9, 299.

[28] Rong J., Jing Z., Li H. and Sheng M.: Macromol. Rapid Commun., 2001, 22, 329.

[29] Tajima K. and Aida T.: Chem. Commun., 2000, 24, 2399.

\section{ЕКСТРУЗІЙНА ПОЛІМЕРИЗАЦІЯ ЕТИЛЕНУ ГЕТЕРОГЕННИМИ ДВОКОМПОНЕНТНИМИ КАТАЛІЗАТОРАМИ ЦИГЛЕРА-НАТТА}

Анотація. На основі $\mathrm{TiCl}_{4}$ ma $\mathrm{TiCl} / \mathrm{MgCl}$ синтезовано МCM-41 та SBA-16 каталізатори з різним мольним співвідношенням $\mathrm{Mg} / \mathrm{Ti}$, які надалі були використані для полімеризачії етилену при атмосферному тиску. Показано, що наноканали носіїв цих каталізаторів слугують наномасштабним реактором полімеризачії, щуо дозволяе під час реакиії екструдувати поліетиленові нановолокна. Вивчено вплив $\mathrm{MgCl}_{2}$ на каталітичну активність $і$ морфологію отриманого поліетилену. Встановлено, що $\mathrm{MgCl}_{2}$ підвищує каталітичну активність і надає каталітичній системі SBA16/MgCl_/TiCl $\mathrm{M}_{4}$ волокнистої структури.

Ключові слова: полімеризація Циглера-Натта, поліетилен, екструзійна полімеризація, нановолокно. 